\title{
Accounting
}

\section{The effect of supervisor's authority on auditor's response}

\author{
Yustinus Tito Susilo ${ }^{a *}$, Meinarni Asnawia and Anthonius H. Citra Wijaya ${ }^{a}$
}

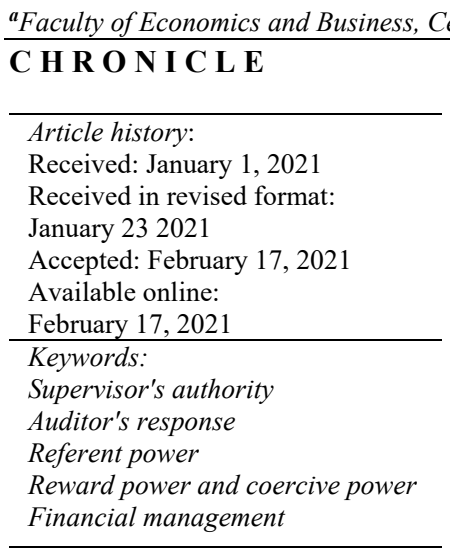

(C) 2021 by the authors; licensee Growing Science, Canada

\section{Introduction}

Audit engagements are carried out by a team of several auditors. In the team, there is one person who acts as the team leader and several people who act as team members. Another auditor who has a higher position acts as a Technical Controller, which is in charge of carrying out audit supervision. To produce a quality audit, the audit supervisor must carry out a review. In this review process, the supervisor will ask the audit team for things that are unclear or different from the auditor. The auditor is obliged to answer questions raised by the supervisor. This can result in mental stress or stress on auditors. Fedor and Ramsay (2007) stated that auditors often feel that reviewing working papers is something negative for them because supervisors usually focus more on the lack of audit work papers. Therefore, auditors often use impression management strategies to reduce excessive evaluation. The auditor tries to convince the supervisor about the validity of the alternative procedures carried out by providing arguments about the technical obstacles faced in conducting the audit. Supervisors conduct a review of the examiner's work paper, in addition to supervising the examiner's performance, also to provide feedback for the examiner (Solomon and Shields, 1995). Formal feedback is part of the formal structure of the organization's performance appraisal system, while informal feedback is part of the interaction between supervisors and subordinates. Supervisors as an external source of feedback are one of the important factors that influence auditors' responses to improve their performance (Fedor et al., 2001). The supervisor's authority has a fundamental role in cognitive, social, and emotional behavior. This role is in how the auditor responds to feedback (Lee and Tiedens 2001). Referent and expert have a positive relationship with performance, while coercive has a negative relationship with performance (Fedor \& Ramsay, 2007).

* Corresponding author.

E-mail address: ytsusilo.uncen@gmail.com (Y. T. Susilo) 
Research on supervisor's authority in preparing responses in audit reviews or work papers has been carried out by several previous researchers such as research conducted by Januarti and Ghozali (2013), Averina and Sihombing (2013), Tina Dacin et al. (2002), Marunduh and Mawikere (2016), and Fedor and Ramsay (2007) whose research results show that Supervisor power influences Preparer's Responses, namely where referent power and coercive power do not affect responses in audit reviews while expert power, feedback and work experience affect responses in reviews. audit. There are differences in the results of research on the influence of supervisors' authority in preparing responses in audit reviews as well as limited research on responses in audit reviews in Papua, allowing researchers to conduct the same research. This study is a development of previous research on supervisor power and auditor experience influencing auditor's response by Januarti \& Ghozali (2013) using the same variables but with different research locations. So, the purpose of this study is to examine and analyze the effect of referent power, expert power, legitimate power, reward power, and coercive power on performance improvement and impression management.

\section{Literature Review and Hypothesis}

\subsection{Referent Power on Performance Improvement and Impression Management}

The referent power comes from the interpersonal relationship of a supervisor with colleagues and subordinates. Due to good interpersonal relationships, auditors will find it easier to approach supervisors and ask questions during reviews, so that in general, referent power is considered a positive power related to performance improvement (Fedor \& Ramsay, 2007). Fedor and Ramsay (2007) also proved that referent power has a positive effect on performance improvement and that generally referent power is considered a positive power related to performance improvement. Nurrahmat, \& Januarti, (2015) stated that the feedback loop is the basis of a series of actions. In its simplest form, a feedback loop consists of four elements, a referenced standard or goal, a sensor or input function, a comparator, and an effector or output function. In a simple feedback sequence, the input is accepted by the sensor, which then sends a signal to the comparator, in which the input is tested by the standard.

If this comparison raises a mismatch, an error signal is generated, and the system will take action via the effector to reduce the mismatch. This process of feeling, comparing, and influencing is repeated until the discrepancy is gone. Moreover, referent power is considered a positive form of power because it is in line with the idea of role modelling (Wood and Bandura 1989; Nurrahmat, \& Januarti,, 2015). A subordinate will feel more comfortable working with supervisors who have referent power, especially those they respect personally as supervisors (French and Raven 1959). The auditor will try to get a good assessment and impression from the supervisor. Therefore, the auditor will make impression management during the review. Januarti and Ghozali (2013) and Fedor and Ramsay (2007) proved that referent power has a positive influence on impression management.

H1a: Referent power has a positive effect on performance improvement.

H2a: Referent power has a positive effect on impression management.

\subsection{Expert Power on Performance Improvement}

The knowledge and information and experience shared by supervisors will also help auditors to improve their work performance. Those who have expert power are considered to have something valuable and useful knowledge (French \& Raven 1959; Nurrahmat, \& Januarti, 2015). Januarti and Ghozali (2013) empirically proved that expert power has a positive effect on performance improvement. Apart from trying to improve performance, auditors will also do impression management to avoid a bad impression of themselves in the eyes of supervisors. The auditor will try to give a good impression in order to keep access to the knowledge and information that the supervisor has (Fedor \& Ramsay, 2007). Therefore, expert power is expected to have a positive influence on impression management.

$\mathrm{H}_{1 \mathrm{~b}}$ : Expert power has a positive effect on performance improvement.

$\mathrm{H}_{2 \mathrm{~b}}$ : Expert power has a positive effect on impression management.

\subsection{Legitimate Power on Performance Improvement and Impression Management}

Hinkin and Schriesheim (1989), Nurrahmat, \& Januarti, (2015) state that legitimate power is the ability to give a sense of duty and responsibility to others. During the review, the supervisor's legitimate power is a letter of assignment as the audit team supervisor. The audit team answers to the supervisor. As individuals in the organization, auditors are required to obey the rules and orders imposed on them. Januarti \& Ghozali (2013) proved that expert power has a positive effect on performance improvement. The assignment letter gives the supervisor the power to criticize and instruct the auditor according to his judgment. The auditor will try not to get a negative assessment during the review and the negative impact of the review. Apart from 
preparing the review material properly, auditors can also do impression management to reduce the negative impact of the review. Therefore, in this study, legitimate power is expected to have a positive effect on performance improvement.

$\mathrm{H}_{1 \mathrm{c}}$ : Legitimate power has a positive effect on performance improvement.

$\mathrm{H}_{2 \mathrm{c}}$ : Legitimate power has a positive effect on impression management.

\subsection{Reward Power on Performance Improvement and Impression Management}

The auditor uses the supervisor's input or notes as a mismatch between objectives and reality. The objective of the auditor is to conduct an audit in accordance with applicable audit standards and to minimize corrections / records of differences from the supervisor. According to control theory, if there are many differences, auditors must make changes in behavior to adjust the results to the applicable standards (Sunyoto et al., 2019). This change in behavior then results in the auditor's performance improvement. In addition, when there is a possibility of a negative review from a supervisor, the auditor will try to reduce the negative review by making impression management. In accordance with Control theory, the auditor does impression management so that the situation is in accordance with what the auditor expects. So, the use of control theory can control the variables of referent power, expert power, legitimate power, reward power and coercive power on performance improvement and impression management (Hayati, 2016). Its strategic objective is to build a company image that satisfies stakeholders as well as obtaining recognition of conformity with normative rules in the company's institutional environment. So, with selfpromotion and acclaiming roles, institutions get an appreciation for institutional values and norms (Stanton et al. 2004). Therefore, it can be concluded that supervisors have the ability to provide incentives indirectly to auditors that the supervisor likes. The auditor will try to give a good impression at the time of the review by showing performance improvement in order to have a good impression on the view of the supervisor.

$\mathrm{H}_{1 \mathrm{~d}}$ : Reward power has a positive effect on performance improvement.

$\mathrm{H}_{2 \mathrm{~d}}$ : Reward power has a positive effect on impression management.

\subsection{Coercive Power on Performance Improvement and Impression Management}

Coercive power often has a negative influence on organizational outcomes (Carson et al. 1993; Nurrahmat, \& Januarti, 2015). Coercive power can provide supervisors with the compliance desired but often results in unwanted auditor behavior. A punishment that is given often does not produce the desired performance improvement (Fedor \& Ramsay, 2007). Januarti \& Ghozali (2013) and Fedor \& Ramsay (2007) proved that coercive power has a negative effect on performance improvement. Coercive power can interfere with the relationship between superiors and subordinates because of the possibility of fear of subordinates. Regarding the relationship with impression management, there are two possibilities. The first possibility is that auditors will attempt to do impression management to avoid supervisors using coercive power against them. The next possibility is that auditors will avoid doing impression management. This second behavior is in accordance with avoidance behavior, namely that subordinates prefer to avoid emotionally from supervisors who can give them punishment. Therefore, in this study, coercive power is expected to have a negative influence related to performance improvement and impression management.

$\mathrm{H}_{1 \mathrm{e}}$ : Coercive Power has a negative effect on performance improvement.

$\mathrm{H}_{2 \mathrm{e}}$ : Coercive Power has a negative effect on impression management.

\section{Research Methods}

The research location was at the Representative of the Papua Province Development and Finance Supervisory Agency (BPKP). The selection of the agency that is used as the location in this study is based on the phenomenon in the background of the problem. The population in this study were all auditors at the BPKP Representatives of Papua Province as many as 84 people. Sampling using the nonprobability sampling method, in practice only 60 auditors filled out the questionnaire, while the other 24 auditors had not entered the office because they were still on leave together. To process the data, data analysis tools are used using the Structure Equation Model (SEM) approach with the Partial Least Square (PLS) method using WrapPLS 5.0 software (Ghozali \& Latan, 2014).

\section{Results and Discussion}

The results of output latent variable coefficients were presented in Table 1, while the results of coefficient among latent variables were in Table 2. 
Table 1

Output Latent Variable Coefficients

\begin{tabular}{lccccccl}
\hline & RTP & EP & LP & RDP & CP & PI & IM \\
\hline R-squared & & & & & & 0.076 & 0.384 \\
Adj. R- squared & & & & & & 0.010 & 0.328 \\
Composite Reliability & 0.856 & 0.935 & 0.943 & 0.927 & 0.899 & 0.904 & 0.804 \\
Cronbach's alpha & 0.772 & 0.913 & 0.925 & 0.901 & 0.858 & 0.867 & 0.672 \\
Avg. var. extract & 0.588 & 0.744 & 0.769 & 0.718 & 0.644 & 0.654 & 0.512 \\
Full Collin. VIF & 1.451 & 3.102 & 3.526 & 1.272 & 1.505 & 1.878 & 1.375 \\
Q-squared & & & & & & 0.563 & 0.389 \\
\hline
\end{tabular}

Table 2

Coefficient Among Latent Variables

\begin{tabular}{llllllll}
\hline & RTP & EP & LP & RDP & CP & PI & IM \\
\hline R-squared & $(0.767)$ & 0.205 & 0.144 & -0.086 & 0.261 & 0.107 & 0.360 \\
Adj. R- squared & 0.205 & $(0.862)$ & 0.798 & 0.301 & -0.329 & 0.615 & 0.182 \\
Composite Reliability & 0.144 & 0.798 & $(0.877)$ & 0.394 & -0.440 & 0.586 & 0.145 \\
Cronbach's alpha & -0.086 & 0.301 & 0.394 & $(0.848)$ & -0.112 & 0.201 & -0.143 \\
Avg. var. extract & 0.261 & -0.329 & -0.440 & -0.112 & $(0.802)$ & -0.230 & -0.082 \\
Full Collin. VIF & 0.107 & 0.615 & 0.586 & 0.201 & -0.230 & $(0.809)$ & 0.334 \\
Q-squared & 0.360 & 0.182 & 0.145 & -0.143 & -0.082 & 0.334 & $(0.716)$ \\
\hline
\end{tabular}

For validity testing, based on the value of Combined-Loading and Cross-Loading Output, it is found that almost all indicators have a loading factor value $>0.7$. The IM. 4 indicator shows a loading factor value below 0.5 so it must be removed or eliminated from the model. The results of composite reliability and Cronbach's Alpha as the basis for validity and reliability testing were presented in Table 3.

Table 3

Composite Reliability and Cronbach's Alpha

\begin{tabular}{llll}
\hline Variable & $\begin{array}{l}\text { Composite } \\
\text { Reliability }\end{array}$ & Cronbach's Alpha & \\
\hline Referent Power & 0.856 & 0.772 & Reliable \\
Expert Power & 0.935 & 0.913 & Reliable \\
Legitimate Power & 0.943 & 0.925 & Reliable \\
Reward Power & 0.927 & 0.901 & Reliable \\
Coercive Power & 0.899 & 0.858 & Reliable \\
Performance Improvement & 0.904 & 0.867 & Reliable \\
Impression Management & 0.804 & 0.670 & Reliable \\
\hline
\end{tabular}

Inner model test by looking at the adjusted R-Square value where the coefficient of determinant adjusted R-Square shows that performance improvement and impression management variables can be explained by referent power, expert power legitimate power, reward power and coercive power by 33\% and the remaining 67\% explained other factors that are not in the model. Besides looking at the R-square value, a model is considered to have a relevant predictive value if the Q-square value is greater than $0(>0)$. The Q2 value predictive relevance of the local government performance variable is $0.389>0$, this indicates that the model has predictive relevance. Furthermore, to assess the results of a model it is said to be fit in the Wrap-PLS 5.0 program it can be seen from the general results output. Table 4 showed the fit indices and p-value model displays the results of ten fit indicators, it is known that the value obtained from the ten criteria is only three that have not been met, so it can be said that the model has met the prerequisites for the fit model.

The results showed that referent power has a negative and significant effect on performance improvement. It is acceptable and proven from the test results, it can be seen that the value of the path coefficients, the effect of referent power on performance improvement is -0.231 and significant at 0.028 , less than $p$-value $<0.05$ so that the proposed hypothesis is accepted. The results of this study are in line with research (Fedor \& Ramsay, 2007; DiMaggio \& Powell, 1983). Moreover, internal control has a positive and significant effect on impression management, it can be seen that the value of path coefficients is 0.305 and significant at 0.005 , which is less than $p$-value $<0.05$ so that the proposed hypothesis is accepted. The results of this study are in line with the research of Januarti and Ghozali (2013) and Fedor and Ramsay (2007) proving that referent power has a positive effect on impression management (Table 5). 
Table 4

Model Fit and Quality Indices

\begin{tabular}{|c|c|c|c|c|}
\hline Model fit and quality indices & Index & p-value & Criteria & \\
\hline Average path coefficient & 0.322 & 0.002 & $\mathrm{P}<0.05$ & Accepted \\
\hline Average R-squared & 0.230 & 0.015 & $\mathrm{P}<0.05$ & Accepted \\
\hline Average adjusted R-squared & 0.159 & 0.050 & $\mathrm{P}<0.05$ & Marginal \\
\hline Average block VIF (AVIF) & 3.621 & \multicolumn{2}{|c|}{$\leq 5$ and ideally $\leq 3.3$} & Accepted \\
\hline Average full collinearity VIF (AFVIF) & 2.016 & \multicolumn{2}{|c|}{$\leq 5$ and ideally $\leq 3.3$} & Accepted \\
\hline Tenenhaus GoF (GoF) & 0.390 & \multicolumn{2}{|c|}{$\begin{array}{l}\text { Small } \geq 0.1, \\
\text { Medium } \geq 0.25 \\
\text { Large } \geq 0.36\end{array}$} & Accepted \\
\hline Sympson's paradox ratio (SPR) & 0.600 & \multicolumn{2}{|c|}{$\geq 0.7$ and ideally $=1$} & Marginal \\
\hline R-squared contribution ratio (RSCR) & 0.678 & \multicolumn{2}{|c|}{$\geq 0.9$ and ideally $=1$} & Marginal \\
\hline Statistical suppression ratio (SSR) & 0.700 & \multicolumn{2}{|l|}{$\geq 0.7$} & Accepted \\
\hline Nonlinear bivariate causality direction ratio (NLBCDR) & 1.000 & \multicolumn{2}{|l|}{$\geq 0.7$} & Accepted \\
\hline
\end{tabular}

Furthermore, statistical output showed that expert power has a positive and insignificant effect on performance improvement, where the results are proven from the test results, it can be seen that the value of path coefficients is 0.164 and not significant at 0.092 , greater than $p$-value $<0.05$ so the proposed hypothesis is rejected. The results of this study are not in line with the research of Januarti and Ghozali (2013) in which expert power has a positive effect on performance improvement. The results of this study also do not support the control theory developed (Wiener, 2019; Nurrahmat, \& Januarti,, 2015), which can be applied to auditor behavior when the audit review is carried out. In addition, expert power is also empirically proven to have a negative effect on impression management, path coefficients is -0.158 with $p$-value of $0.101(>0.05)$, so the proposed hypothesis is rejected.

In terms of the effects of legitimate power, it is empirically proven have no significant effect on performance improvement. It can be accepted and proven true. From the test results, it can be seen that the value of path coefficients, the effect of legitimate power on performance improvement is 0.035 and not significant at $p$-value of $0.392(<0.05)$ so that the proposed hypothesis is rejected. In addition, legitimate power does not affect impression management, the value of path coefficients is 0.082 with a pvalue of 0.257 or greater than $\mathrm{P}>0.05$ so the proposed hypothesis is rejected. The results of this study are not in line with the research of Januarti and Ghozali (2013) proving that legitimate power has a positive effect on impression management, as individuals in organizations, auditors are obliged to obey the rules and orders imposed on them. The analysis also showed that reward power has a negative and significant effect on performance improvement, where the path coefficients value is -0.600 with a $p$-value $<0.001(>0.05)$, so that the proposed hypothesis is accepted. The results of this study are in line with Nurrahmat, and Januarti, (2015) which shows that reward power has a positive effect on performance improvement. The analysis showed that reward power has a positive and significant effect on impression management, the value of path coefficients is 0.787 with a $p$-value $<0.001(\mathrm{P}>0.05)$, so that the proposed hypothesis is accepted. The results of this study are in line with Nurrahmat and Januarti, (2015), which shows that reward power has a positive effect on impression management.

\section{Table 5}

Output Path Coefficients Model Indirect and Total Effects

\begin{tabular}{llll}
\hline Variable & Path & $\boldsymbol{p}$-value & Confirmation \\
\hline RF $\rightarrow$ PI & -0.231 & 0.028 & Accepted \\
RF $\rightarrow$ MI & 0.305 & 0.005 & Accepted \\
EP $\rightarrow$ PI & 0.164 & 0.092 & Rejected \\
EP $\rightarrow$ MI & -0.158 & 0.101 & Rejected \\
$\mathbf{L P} \rightarrow$ PI & 0.035 & 0.392 & Rejected \\
$\mathbf{L P} \rightarrow$ MI & 0.082 & 0.257 & Rejected \\
$\mathbf{R P} \rightarrow$ PI & -0.600 & $<0.001$ & Accepted \\
$\mathbf{R P} \rightarrow$ MI & 0.787 & $<0.001$ & Accepted \\
$\mathbf{C P} \rightarrow$ PI & -0.506 & $<0.001$ & Accepted \\
$\mathbf{C P} \rightarrow$ MI & -0.354 & 0.001 & Accepted \\
\hline
\end{tabular}

$\mathrm{RF}=$ referent power; $\mathrm{PI}=$ performance improvement; $\mathrm{MI}=$ management impression; $\mathrm{EP}=$ expert power; $\mathrm{LP}=$ legitimate power; $\mathrm{RP}=$ reward power; $\mathrm{CP}=$ coercive power 
The hypothesis testing showed that coercive power has a negative and significant effect on performance improvement, it can be seen that the path coefficients value is -0.506 with a $p$-value $<0.001(>0.05)$, so that the proposed hypothesis is accepted. The results of this study are in line with the research of Januarti \& Ghozali (2013) and Fedor \& Ramsay (2007) show that coercive power has a negative effect on performance improvement. However, coercive power does not affect impression management, the value of path coefficients is -0.354 with a p-value of $0.001(>0.05)$, so that the proposed hypothesis is accepted. The results of this study are in line with the research of Januarti \& Ghozali (2013) and Fedor \& Ramsay (2007) where the results of their research show that coercive power does not affect impression management.

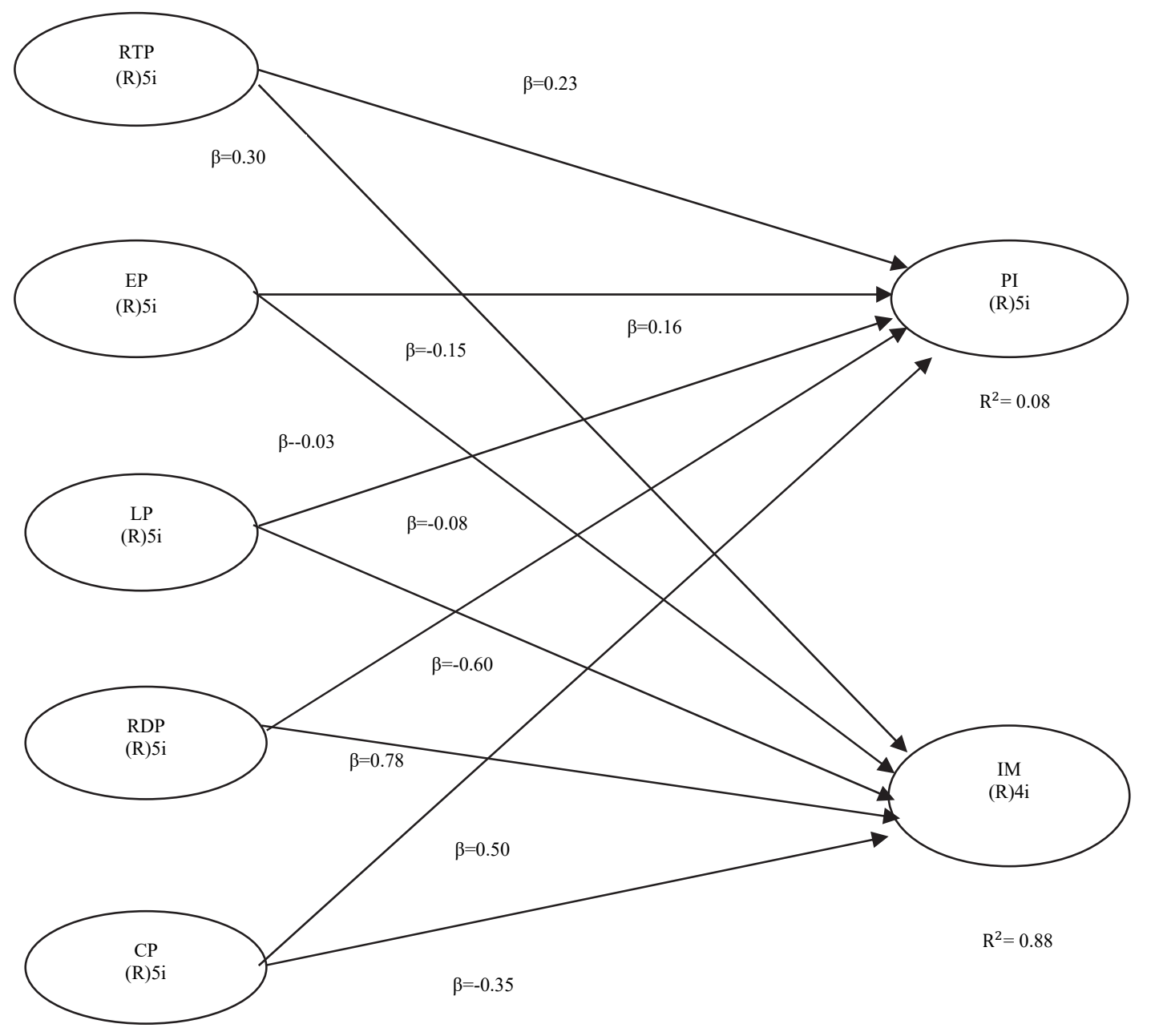

Fig. 1. Output Warp-PLS 5.0

\section{Conclusions}

The results showed that referent power, reward power, and coercive power affected performance improvement and impression management, while expert power and legitimate power did not affect performance improvement and impression management. Regarding that expert power has no effect on performance improvement, it is related to technical knowledge possessed by supervisors cannot be fully applied in the field or the auditor's lack of knowledge of new technical knowledge in implementing audit work programs. Also, for audit assignments whose guidelines have been determined from the head office, the work steps that must be carried out refer to these guidelines, although it is possible to make refinements.

Further research can expand research in other government supervision institutions or government external auditors as well as to use variable reward power which is used as a moderating variable. Practically, the government supervision institutions need to provide advice, supervisors to communicate from the beginning of the assignment about the expected work standards and if the agreed work standards are deemed insufficient. Moreover, it should be revised within the assignment period and refer to the assignment guidelines, although it is possible to do sharpening, then the supervisor can provide reviews and suggestions given regarding technical audits. 


\section{References}

Averina, M., \& Sihombing, R. P. (2013). The Effect of Discussion on Audit Working Paper Reviews on Motivation and Performance of Auditors in Public Accountants in Semarang. Journal of Business Accounting, 12(23), $71-97$.

Bandura, A., \& Wood, R. (1989). Effect of perceived controllability and performance standards on self-regulation of complex decision making. Journal of Personality and Social Psychology, 56(5), 805.

Carson, P. P., Carson, K. D., \& Roe, C. W. (1993). Social Power Bases: A Meta - Anaiytic Examination of Interrelationships and Outcomes. Journal of Applied Social Psychology, 23(14), 1150-1169.

DiMaggio, P. J., \& Powell, W. W. (1983). The iron cage revisited: Institutional isomorphism and collective rationality in organizational fields. American Sociological Review, 147-160.

Fedor, D. B., Davis, W. D., Maslyn, J. M., \& Mathieson, K. (2001). Performance improvement efforts in response to negative feedback: The roles of source power and recipient self-esteem. Journal of Management, 27(1), 79-97.

Fedor, D. B., \& Ramsay, R. J. (2007). Effects of supervisor power on preparers' responses to audit review: A field study. Behavioral Research in Accounting, 19(1), 91-105.

French, J. R., Raven, B., \& Cartwright, D. (1959). The bases of social power. Classics of organization theory, 7, $311-320$.

Ghozali, I., \& Latan, H. (2014). Partial Least Squares concepts, methods and applications using the WarpPLS 4.0 program. Semarang: Diponegoro University Publishing Agency.

Hayati, D. I. (2016). The influence of good corporate governance (GCG) on health management (Empirical Study of Manufacturing Companies Listed on the Indonesia Stock Exchange in 2014). Journal of Accounting, 4(1).

Hinkin, T. R., \& Schriesheim, C. A. (1989). Development and application of new scales to measure the French and Raven (1959) bases of social power. Journal of applied psychology, 74 (4), 561.

Januarti, I., \& Ghozali, I. (2013). Supervisor Power and Auditor Experience Influencing Auditor's Response. Research Journal of Finance and Accounting, 4(2), 8-20.

Lee, F., \& Tiedens, L. Z. (2001). 2. Is it lonely at the top ?: The independence and interdependence of power holders. Research in organizational behavior, 23, 43-91.

Marunduh, A., \& Mawikere, L. (2013). The Influence of Verbal Discussions in the Audit Working Paper Review on Auditor Performance at the BPK RI Representative Office of North Sulawesi. Accountability, 2(1), 176-184.

Nurrahmat, N., \& Januarti, I. (2015). The effect of supervisor power on the auditor's response to BPK RI examiners (Doctoral dissertation, Faculty of Economics and Business).

Shields, M., Solomon, I., \& Jackson, K. D. (1995). Experimental research on tax professionals' judgment and decision making. Behavioral tax research: Prospects and judgment calls, 3, 77-126.

Stanton, P., Stanton, J., \& Pires, G. (2004). Impressions of an annual report: an experimental study. Corporate Communications: An International Journal.

Sunyoto, Y., Lely, N., \& Agus, A. (2019). The influence of experience, motivation and professional commitment on employee performance and job satisfaction at the audit firm in Indonesia. Revista Espacios, 40(27).

Tina Dacin, M., Goodstein, J., \& Richard Scott, W. (2002). Institutional theory and institutional change: Introduction to the special research forum. Academy of Management Journal, 45(1), 45-56.

Wiener, N. (2019). Cybernetics or Control and Communication in the Animal and the Machine. MIT press. 
(C) 2021 by the authors; licensee Growing Science, Canada. This is an open access article distributed under the terms and conditions of the Creative Commons Attribution (CC-BY) license (http://creativecommons.org/licenses/by/4.0/). 